But he does draw attention in passing to an error that is apt to underlie discussions of trends in the birth rate.

Graphs are published from time to time showing the ups and downs of the annual birth rate, and we are familiar enough with the thought that today's crest may lead into tomorrow's trough. Fluctuations may be no more than ripples on a pond. This does not stop commentators from attributing a dip to a new contraceptive or a sudden flush of babies to an electricity failure. They may even be right, though chance might equally be the explanation. But what is less often considered is something much more important than the annual birth rate, and that is the size of completed families. For great changes in the birth rate are compatible with continuing uniformity of completed family size if many women decide to have children later, or sooner, after they get married, or if they increase, or decrease, the intervals between the births of their children. There is evidence that these factors have been at work and that despite falling annual birth rates in recent years the size of the families when they are ultimately completed will shəw little change. But the Government Actuary does forecast a slight reduction in accordance with present trends. A household survey has shown that women recently married expect to have slightly smaller families (average, under 2.3 children) than a comparable sample of women interviewed in 1967 (average, 2.5 children). But, since many thousands of pregnancies are still unintentional $^{2}$ despite the general availability of contraceptives, are these expectations likely to be fulfilled?

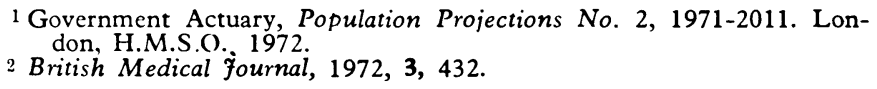

\section{Viruses of Vomiting}

Next to acute respiratory disease, acute vomiting and diarrhoea is one of the commonest diseases in the community, though cases are rarely admitted to hospital. ${ }^{1}$ Much is known about those due to acute bacterial infections with shigellae and salmonellae and also to pathogenic Escherichia coli in infancy and in some outbreaks of travellers' diarrhoea. But other causes of such outbreaks of disease also exist.

An important study by J. Zahorsky ${ }^{2}$ in the United States showed that a disease that spread in families with a high secondary attack rate and was characterized by vomiting was occurring in his practice in the winter, when bacterial infections, common in those years, were infrequent. He called the disease "winter vomiting disease," and a similar disease was noted in Britain in families and in closed institutions.3-5 No pathogenic bacteria were isolated, and repeated studies, mostly unpublished, of such outbreaks have failed to show any viruses at all. Nevertheless the disease continues to cause trouble.

Pathogenic bacteria are not grown from many isolated cases of diarrhoea and vomiting in children, and these might represent cases of winter vomiting disease. Many viruses, particularly enteroviruses such as echoviruses and Coxsackie viruses, have been isolated in tissue cultures and animals from gastroenteritis in infants and small children, but wherever the same amount of effort was expended in isolating viruses from a matched group of children without the disease nearly the same proportions of the same viruses have been isolated. ${ }^{6-11}$ This is a slight exaggeration, for a rather higher proportion of certain viruses such as enteroviruses and adenoviruses have sometimes been observed in sick children, and occasional outbreaks have occurred in which gastrointestinal symptoms were associated with infection with a single virus from these groups. But the most that can be concluded is that a small percentage of gastroenteritis cases were due to the viruses isolated. ${ }^{12-15}$

Yet there has been evidence for years that cases of gastroenteritis are due to virus infections. Faecal extracts from adult cases were passed through bacteria-tight filters and caused typical disease when given by mouth to volunteers. ${ }^{16-18}$ Sometimes the volunteers were not strictly isolated, sometimes they were. Moreover there appeared to be two types of virus, one causing a more severe disease than the other, and there was immunity to reinfection with the same virus but not to infection with the other one, ${ }^{19}$ suggesting that they belonged to distinct serotypes.

The Public Health Laboratory Service set up a committee to work on the problem about 10 years ago. ${ }^{20}$ It studied selected outbreaks in schools and found that only faeces transmitted the disease to volunteers. These workers transmitted the disease serially, and in collaboration with workers at the Medical Research Council's Common Cold Unit showed that it had the clinical features observed in schools, namely, vomiting with some diarrhoea and fever. It thus received the name "epidemic vomiting." By filtration and other treatments they showed that it was due to a small ether-stable particle, and its properties were compatible with its being a picornavirus or parvovirus.

The results of similar studies in the U.S.A. were published at about the same time. The original material came from an outbreak of non-bacterial "gastroenteritis."21 Its effects in volunteers were described, 22 and, as in Britain, a high proportion of volunteers seemed to be susceptible, though on re-exposure they were resistant. ${ }^{23}$ The properties were similar to those described in Britain, and in addition the agent seemed to be able to withstand acid treatment and heat at $60^{\circ} \mathrm{C}$. These workers suggested it might be a parvovirus, but neither group can precisely identify the agent yet. Nevertheless the U.S. virus, Norwalk, produces a disease in British volunteers which resembles that produced by the local virus, and they may well be similar.

For much further progress to be made it is necessary to grow the virus in the laboratory, and in this respect the situation is tantalizing. Despite the trial of a variety of organ culture techniques which had been developed to grow the viruses of gastroenteritis of animals ${ }^{24-30}$ the human virus failed to grow. ${ }^{20} 32$ Now after a lapse of some years wellcharacterized virus-containing material is again under study. We know more about these viruses than we did, and new techniques for growing viruses from the gut are appearing. Consequently progress is possible in a way that will open this virus to study in detail and so elucidate the disease it causes.

These diseases may interest other specialists beside those in communicable diseases. Preliminary studies on American volunteers have shown that they had transient depression of absorption of D-xylose and fat and rather longer lasting failures of lactose absorption, apparently due to lactase deficiency. ${ }^{31}$ It would be of interest to unravel the reasons for these changes. Does the virus destroy epithelial cells or interfere with enzyme production or absorption in a more subtle way? Such a change might be important in a child or adult in a malnourished state or with an underlying malabsorption disease.

A considerable proportion of children admitted to hospital 
in Britain with gastroenteritis, and probably in the tropics too, may be suffering from infections with such a virus. But until reliable specific tests are available it is impossible to contradict the substantial number of paediatricians and bacteriologists who think that bacteria are the main causes.

1 Dingle, J. H., et al., American fournal of Hygiene, 1956, 64, 368.

2 Zahorsky, J., Archives of Pediatrics, 1929, 46, 391.

3 Gray, J. D., British Medical fournal, 1939, 1, 209.

4 Gray, J. D., British Medical fournal, 1939, 1, 209.

5 Miller, R., and Raven, M., British Medical fournal, 1936, 1, 1242

${ }^{6}$ Cramblett, H. G., and Siewers, C. M. F., Pediatrics, 1965, 35, 885.

7 Bell, E. J., and Grist, N. R., British Medical fournal, 1967, 4, 741.

Parks, W. P., Melnick, J. L., Queiroga, L. T., and Ali Khan, H., American Fournal of Epidemiology, 1966, 84, 382.

9 Ramos-Alvarez, M., and Olarte, J., American fournal of Diseases of Children, 1964, 107, 218.

0 Stott, E. J., Bell, E. J., Eadie, M. B., Ross, C. A. C., and Grist, N. R., Fournal of Hygiene, 1967, 65, 9.

11 Yow, M. D., Melnick, J. L., Blattner, R. J., and Rasmussen, L. E., American fournal of Hygiene, 1963, 77, 283.

12 Eichenwald, H. F., Ababio, A., Arky, A. M., and Hartman, A. P., Fournal of the American Medical Association, 1958, 166, 1563.

${ }^{13} \mathrm{Klein}, \mathrm{J}$. O., Lerner, A. M., and Finland, M., American fournal of Medical Sciences, 1960, 140, 749 .

14 Kjellen, L., Zetterberg, B., and Svedmyr, A., Acta Pediatrica, 1957, 46, 561.

15 Sabin, A. B., Science, 1959, 130, 1387.

${ }^{6}$ Gordon, I., Ingraham, H. S., and Korns, R. F., Fournal of Experimental Medicine, 1947, 86, 409

7 Reiman, H. A., Price, A. H., and Hodges, J. H., Proceedings of the Society of Experimental Biology and Medicine, 1945, 59, 8

8 Yamamoto, A., Zennyoji, H., Yanagita, K., and Kato, S., Fapanese Medical fournal, 1948, 1, 379

19 Gordon, I., Patterson, P. R., and Whitney, E., fournal of Clinical Investigation, 1956, 35, 200.

20 Clarke, S. K. R., et al., British Medical fournal, 1972, 3, 86.

21 Adler, J. L., and Zickl, R., Fournal of Infectious Diseases, 1969, 119, 668.

22 Dolin, R

23 Dolin, R., et al., Proceedings of the Society for Experimental Biology and Medicine, $1972,140,578$.

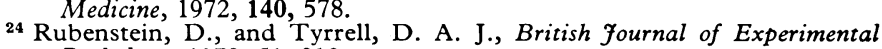
Pathology, 1970, 51, 210.

25 Dolin, R., Blacklow, N. R., Malmgren, R. A., and Chanock, R. M., Fournal of Infectious Diseases, 1970, 122, 227.

26 Stenhouse, A. C., fournal of General Virology, 1970, 8, 235

Rubenstein, D., Tyrrell, D. A. J., Derbyshire, J. B., and Collins, A. P., Nature, 1970, 227, 1348.

28 Tajima, M., Archiv fuer die gesamte Virusforschung, 1970, 29, 105

9 Rubenstein, D., Milne, R. G., Buckland, R., and Tyrrell, D. A. J., British fournal of Experimental Pathology, 1971, 52, 442.

30 Adams, W. R., and Kraft, L. M., American fournal of Pathology, 1967, $51,39$.

${ }^{31}$ Blacklow, N., et al., Annals of Internal Medicine, 1972, 76, 993.

\section{Asthma Deaths: A Question Answered}

After being stable for about a century ${ }^{1}$ the mortality attributed to asthma steadily increased in England and Wales between 1959 and 1966, particularly in young persons. Indeed, at ages 5-24 the mortality from this cause trebled, while in the age group 10-14 the increase was seven-fold making asthma the fourth commonest cause of death in children of this age. Changes in diagnostic criteria or in certification or coding practices could not account for the change, and in a detailed study F. E. Speizer, R. Doll, and $\mathrm{P}$. Heaf ${ }^{2}$ concluded that the increase was real. They also considered that it was unlikely to reflect an increased prevalence of asthma but, rather, an increase in casefatality due to new methods of treatment. Among these were corticosteroids and pressurized aerosols.

The idea was confirmed subsequently when these authors investigated ${ }^{3}$ over 170 consecutive deaths from asthma in young persons, many of which had been unexpected and sudden. More than a quarter of these patients had never received corticosteroids, and in the remainder there was no suggestion that excess use was responsible for the deaths. But, in $84 \%$ of the cases pressurized aerosol bronchodilators were known to have been used, and there was some evidence of their use in excess. Furthermore, the introduction of these preparations, mainly containing isoprenaline, and the increase in their sales correlated well with the epidemic of asthma deaths. M. J. Greenberg ${ }^{4}$ was the first in Britain to stress the possible danger of these drugs if used to excess, and after other reports ${ }^{5-8}$ the Committee on Safety of Drugs issued a warning in June 1967 to all doctors. The next year aerosols were made available on prescription only. Since then both aerosol sales and deaths from asthma have declined, and by early 1969 mortality had almost returned to its pre-epidemic level. ${ }^{9}$

Another study in 1968-9 to determine the extent of abuse of these preparations ${ }^{10}$ suggested that excessive inhalation of bronchodilators had contributed to death in 37\% of the deaths investigated at ages 5-34. Since at the time of this study the epidemic was disappearing, this proportion accorded well with the estimate that only $46 \%$ of these deaths were likely to have been part of the epidemic.

Because these deaths were mainly sudden, unexplained, and often outside hospital, ${ }^{311}$ direct information on the mechanism of death is scanty. Most aerosols in use at the time contained isoprenaline, ${ }^{9}$ a drug with a powerful sympathomimetic action on the heart. It is therefore not difficult to envisage a possible mechanism by which these drugs might cause fatal arrhythmias such as ventricular fibrillation. Furthermore, experimental work on animals has shown that cardiac sensitivity to isoprenaline is increased by hypoxia, 1213 which is frequent during attacks of asthma. Other mechanisms have also been suggested. ${ }^{14-16}$

Strongly suggestive though this circumstantial evidence is, it does not amount to conclusive proof that excessive absorption of sympathomimetic drugs from pressurized aerosols was responsible for the epidemic. Indeed, there were some unexplained geographical variations which cannot be overlooked. ${ }^{16}$ Thus Scotland, Ireland, New Zealand, and Australia shared in the epidemic experienced by England and Wales, but the United States, Canada, and the Netherlands were not affected, while only a small increase was noted in other parts of Europe and in Japan. In Ireland and Australia, as in England and Wales, rising sales of pressurized aerosols corresponded with the increase in asthma deaths, but no information on the consumption of these drugs could be obtained from other countries, and the differences remained unexplained. More recently, however, it was reported that, although this epidemic spared the United States, nevertheless there had been large sales of aerosols. ${ }^{17}$ This might have contradicted the belief that the bronchodilators in the aerosols were responsible and perhaps added weight to the suggestion that the fluorinated hydrocarbons used as propellants might be implicated. Toxic effects from these substances have been observed, including sudden death, 1819 and moreover there are inter-country differences in the types of propellants used. However, a recent discovery by P. D. Stolley goes far to clarify the situation. ${ }^{20} \mathrm{He}$ has convincingly demonstrated a strong positive correlation between increased mortality from asthma and national sales of aerosols delivering a dose of $0.4 \mathrm{mg}$ of isoprenaline per spray. These types are five times as concentrated as other preparations, and they represented about $30 \%$ of aerosol sales in England and Wales during the increase in deaths. Both Canada and the United States did not license the stronger preparations and neither country experienced the epidemic of asthma deaths. Norway was the only Scandinavian country to show a definite rise in these 